\title{
Correlation of Patent Ductus Arteriosus Shunting with Plasma Atrial Natriuretic Factor Concentration in Preterm Infants with Respiratory Distress Syndrome
}

\author{
ERKKI PESONEN, ALLEN T. MERRITT, GREGG HELDT, DAVID J. SAHN, WILLIAM ELIAS, \\ ILKKA TIKKANEN, FREJ FYHRQUIST, AND STURE ANDERSSON \\ Department of Pediatrics, University of California Medical Center, San Diego, California [E. P., A. T. M., G. H., \\ D. J. S., W. E.], Department I and II of Pediatrics, University Central Hospital, Helsinki, Finland [E.P.,S.A.], \\ Unit of Clinical Physiology, Minerva Foundation, Institute for Medical Research, Helsinki, Finland [I. T., F. F.]
}

\begin{abstract}
The concentration of plasma atrial natriuretic factor (ANF) and the mechanism for its secretion were investigated in 17 preterm infants with respiratory distress. Their mean gestational age was 29 wk and $\mathrm{wt}$ $1250 \mathrm{~g}$. The infants were followed during the first week of life by sequential Doppler ultrasound studies. Ductal openness versus closure and amount of ductal flow were correlated with plasma $\mathrm{ANF}$ concentrations. In a subset of $\mathbf{1 0}$ infants, sequential Doppler color flow mapping was used to quantify the ductal flow. During the first $72 \mathrm{~h}$, plasma ANF was high, $361 \mathrm{pg} / \mathrm{mL}$; it decreased to $96 \mathrm{pg} / \mathrm{mL}$ by the end of the 1st wk. The ANF level was significantly higher when the ductus was open than closed (393 versus $123 \mathrm{pg} / \mathrm{mL}, p<0.05$ ). In patients with open ductus and bidirectional foramen ovale shunting $(n=3)$ ANF was 567 $\mathrm{pg} / \mathrm{mL}$ and in those with left-to-right shunt $355 \mathrm{pg} / \mathrm{mL}$ ( $n$ 15, NS). The left atrial size, i.e. the left atrial to aortic root ratio, correlated with the amount of ductal shunting $(r$ $=0.63, p<0.01)$ and with ANF concentration $(r=0.46$, $p<0.02$ ). The correlation of ANF values and the magnitude of left-to-right ductal shunting assessed by color flow mapping was highly significant $(r=0.66, p<0.001)$. In these patients, the elevation of ANF is reflective of ductal flow. (Pediatr Res 27:137-139, 1990)
\end{abstract}

Abbreviations

ANF, atrial natriuretic factor

CFM, color flow mapping

LA/Ao ratio, left atrial to aortic root diameter

PDA, patent ductus arteriosus

Qp/Qs, pulmonic to systemic blood flow ratio

RDS, respiratory distress syndrome

ANF is a secreted from the atria of the heart (1). In term newborns plasma concentration of ANF is increased during the first 2 to $4 \mathrm{~d}$ of life $(2,3)$. ANF has potentially prominent physiologic effects on the circulatory system of the newborn due to its vasodilatory and natriuretic effects and its inhibition of the

Received April 3, 1989; accepted September 22, 1989

Correspondence and reprints Dr. Erkki Pesonen, Children's Hospital, University Central Hospital, Stenbäckinkatu 11, 00290 Helsinki, Finland.

Supported by the Finnish Academy, the Finnish Cultural Fund, the Paulo Foundation, Bernhard Landtman Foundation, Finska Läkaresällskapet, and PHSHL 35036 . release of renin, aldosterone, and vasopressin $(4,5)$. In neonates with RDS (6) plasma concentration of ANF is increased compared to normal newborns. In these patients the peak plasma ANF concentration coincides with the diuretic phase found between 18 to $43 \mathrm{~h}$ of age (7).

To clarify the association of ANF secretion and hemodynamic changes in preterm infants with RDS, we determined the Qp/Qs ratio and ductal closure by CFM with a method we developed previously (8). The focus of this study was the effect of ductal flow on plasma ANF concentration in preterm infants with RDS.

\section{MATERIALS AND METHODS}

Seventeen preterm infants (26-33 wk gestation) with birth wt of 0.66 to $1.95 \mathrm{~kg}$ (mean $1.25 \mathrm{~kg}$ ) developed clinical signs and radiographic features consistent with RDS. Nine infants were delivered by caesarean section, and Apgar scores ranged from 3 to 8 at 1 min (mean 6) and from 6 to 9 at 5 min (mean 8). In 15 infants, analysis of amniotic fluid obtained within $24 \mathrm{~h}$ before birth revealed lecithin/sphingomyelin ratios less than 2.0 with absence of phosphatidylglycerol, and in two remaining infants tracheal aspirates obtained at birth contained no phosphatidylglycerol. These findings and the clinical course were consistent with severe RDS. This was further substantiated by calculating the arteriolar/alveolar oxygen tension ratio (9) at $6 \mathrm{~h}$ of age $(0.17$ \pm 0.08 ; mean $\pm \mathrm{SD}$ ), which confirmed the disturbance in gas exchange and the requirement for supplemental oxygen and mechanical ventilation. Infants included in this study had no evidence of chorioamnionitis, congenital infection, or major malformations.

Blood samples of $0.5 \mathrm{~mL}$ were drawn through umbilical artery catheters into ice-cold EDTA-containing tubes that were rapidly centrifuged at $300 \times g$. Plasma was separated for immediate freezing and stored at $-90^{\circ} \mathrm{C}$ for up to 3 mo before $\mathrm{ANF}$ analysis. From each patient during the 1st wk of life, one to four samples were taken within $3 \mathrm{~h}$ of a CFM study. RIA was carried out as previously described (10). Sensitivity of the method is $5 \mathrm{pg} / \mathrm{mL}$. The intra- and interassay coefficients of variation are 10.6 and $10.4 \%$, respectively. Results were not corrected for recovery.

Ductal patency and closure were determined by serial echocardiograms. The studies were performed either by pulsed Doppler (ATL Mark 8, 7.5 and $10 \mathrm{MHz}$ transducers) or CFM (Toshiba SSH-65A, $5 \mathrm{MHz}$ short focus transducer). M-mode echocardiograms were performed to calculate the LA/Ao ratio. CFM was used in subset of 10 infants to register the ductal and foramen ovale flow patterns. A pulse repetition frequency of $4 \mathrm{kHz}$ was used to get good color density. The frame rate was 30 frames/s. 
The images were stored on a $3 / 4$ inch video tape for later frame by frame analysis.

A high left parasternal view was used to simultaneously visualize the main pulmonary artery, the ductus arteriosus, and the descending aorta. Flow through the foramen ovale was visualized through a subcostal view. A four-chamber view was used to visualize the atrioventricular valves and register regurgitation. Transcutaneous oxygen tension was monitored throughout the examination.

CFM measurements. In CFM both the structures and the flow patterns are seen. Flow toward the transducer is coded in red and that away from the transducer in blue. When visualizing the pulmonary artery from a high left parasternal or a short axis view, the red-coded flow toward the transducer entering the distal pulmonary artery opposite the pulmonary valve level identifies ductal flow (8). The frame showing the largest red area filling the pulmonary artery was chosen for flow measurements. When the ductus arteriosus is patent, the diastolic blue flow away from the transducer represents the swirling backward flow into the pulmonary artery. It strikes the pulmonary valve and then swirls distally into the peripheral pulmonary artery. These abnormal patterns make the pulmonary artery flow turbulent, i.e. there is increased variance of flow velocities within a color pixel. To further analyze these data we used an RGB videodigitizer (Sony SMI 7075) which decodes the color information, on the basis of the intensity of color, to numerical data that are further displayed as a pseudo three-dimensional flow map of the pulmonary artery longitudinal section. Areas of red, blue, and green flow were measured from this three-dimensional plot. Figure 1 shows such a plot of pulmonary artery flow when the ductus arteriosus is open. The percentage of pulmonary artery filled by turbulent green flow has a high correlation to $\mathrm{Qp} / \mathrm{Qs}$ ratio; in animal experiments the correlation coefficient is about $0.9(8)$.

Analysis of variance was used when comparing ANF values in relation to foramen ovale shunting and openness versus closure of the duct. Regression analysis was applied to calculate the correlation between plasma ANF concentration and the Qp/Qs ratio.

The study protocol was approved by the committee for the protection of human subjects of the University of California San Diego Medical Center and informed consent was obtained from the parents to allow their infants' participation.

\section{RESULTS}

The ANF concentrations increased from a level of $239 \mathrm{pg} / \mathrm{mL}$ 1 to $6 \mathrm{~h}$ after birth to a maximum of $867 \mathrm{pg} / \mathrm{mL}$ at the age of $7-12 \mathrm{~h}$, and declined thereafter gradually to $96 \mathrm{pg} / \mathrm{mL}$ between the 4th and 7th $d$ of life. The peak ANF concentrations at 7 to $12 \mathrm{~h}$ of age were significantly higher than in any other age studied $(p<0.05)$ (Fig. 2).

High ANF concentrations appeared in the plasma when the

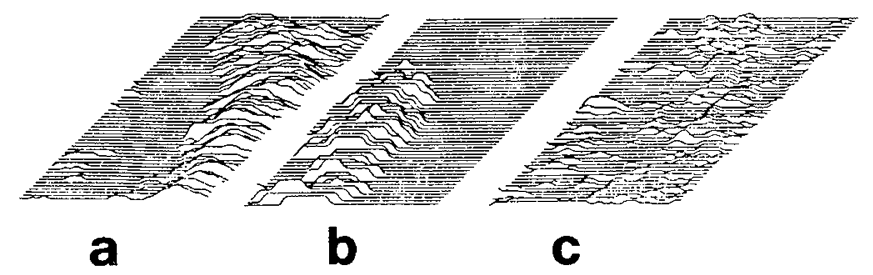

Fig. 1. An example of a diastolic ductal flow analysis from the pulmonary artery. The recording transducer is located above, i.e. on top of the parallelogram. The red-green-blue video-digitizer decodes the color flow information to numerical data that are further displayed in a pseudo three-dimensional flow map. The pulmonary artery longitudinal section filled with a red flow toward the transducer is shown in $a$, blue swirling flow in $b$, and green, i.e. turbulent flow in $c$. The area of green flow was measured as a percentage of pulmonary artery longitudinal sectional area, which is the total area of the parallellogram.

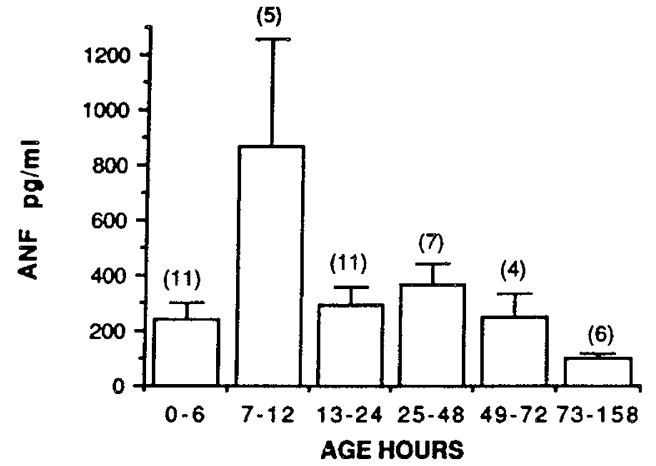

Fig. 2. Plasma ANF concentrations (mean $+\mathrm{SD}$ ) during the first $7 \mathrm{~d}$ of life. Numbers of patients are given in parentheses. The second column is significantly higher than the others $(p<0.05)$.

ductus arteriosus was patent with documented left-to-right shunting. In the scattergram the ANF concentrations are presented against age with ductus open or closed (Fig. 3).

In 15 of the 18 color recordings done on patients with open ductus, there was left-to-right shunting at the atrial level through the foramen ovale. The mean ANF level in these cases was 335 $\mathrm{pg} / \mathrm{mL}$. In three cases, foramen ovale shunting was bidirectional and the ANF was $567 \mathrm{pg} / \mathrm{mL}(p=0.07)$.

The LA/Ao ratio varied between 0.6 and 1.8 (mean $1.1, \mathrm{n}=$ $27)$ and correlated with plasma ANF concentration $(r=0.46, p$ $<0.02$ ). In patients studied with color flow mapping, the percentage of the turbulent, green area in pulmonary artery longitudinal section varied between 0 and 96 . The percentage of turbulent area, i.e. amount of ductal shunting, correlated significantly with LA/Ao ratio $(r=0.63, p<0.01)$. The correlation coefficient between the left-to-right ductal shunting and ANF concentration was $0.66(p<0.001)$ (Fig. 4).

\section{DISCUSSION}

Plasma ANF concentration in full-term infants has been reported to vary during the first days of life between 129 and 356 $\mathrm{pg} / \mathrm{mL}$ and to reach the adult levels of 2 to $109 \mathrm{pg} / \mathrm{mL}$ after $4 \mathrm{~d}$ (2). In small preterm infants with RDS, the concentration of ANF reaches a maximum between 7 and $12 \mathrm{~h}$ of life. These concentrations are 10 times higher than those considered normal in the adult $(2,3,10)$. A highly significant correlation exists between the secretion of ANF and the magnitude of the left-toright shunt in PDA. Ductal flow seems to be of importance for the secretion pattern of ANF in the preterm infant.

In infants with foramen ovale shunting, mitral flow cannot be used to calculate the $\mathrm{Qp} / \mathrm{Qs}$ ratio from the flow through the right ventricular outflow tract and mitral valve (11). Recently, quantitative data have been obtained using pulsed Doppler echocardiography by measuring the mean velocity of diastolic antegrade flow in the proximal left pulmonary artery (12). In small, severely distressed infants, pulsed Doppler echocardiography can be used, but quantitative data are difficult to obtain. CFM serves as a reliable technique both to diagnose ductal patency and to get a close estimate of ductal flow $(8,13)$.

There is a correlation between ANF secretion and left atrial diameter, as quantitated by LA/Ao ratio, but the correlation is stronger with ductal flow as measured by CFM. Increased flow through the lungs leads to left atrial distension $(14,15)$ and leftto-right atrial shunt. Especially in preterm infants there is foramen ovale shunting, and dilatation of the left atrium is limited because foramen ovale allows an almost unrestricted passage of blood from one atrium the other, thereby limiting left atrial enlargement. Moreover, in rapidly varying ductal flow, dilatation of the left atrium is apparently not immediate. In experimental ductus arteriosus, there is no immediate increase of ANF secretion nor left atrial size due to increased flow (16). However, after 


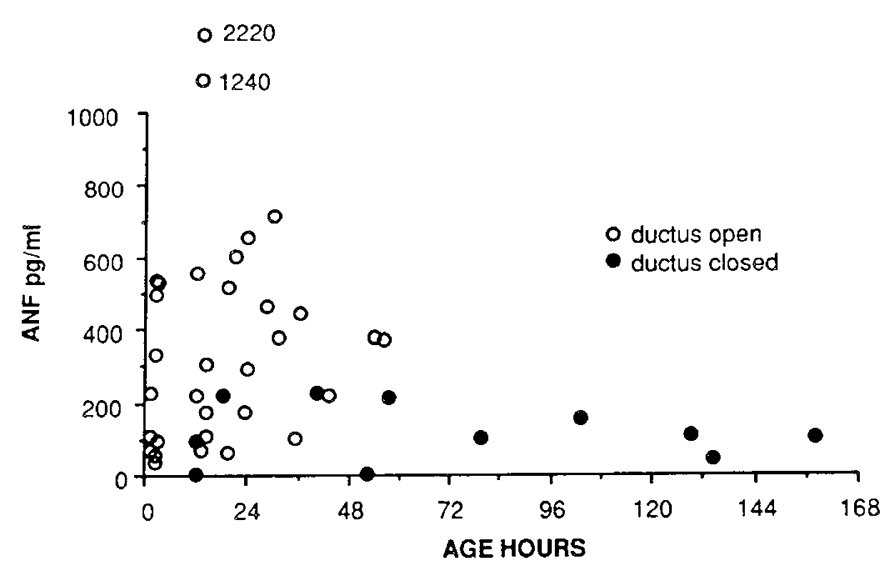

Fig. 3. Plasma ANF concentrations in preterm newborns with RDS and the ductus arteriosus open or closed as a function of age in $h$.

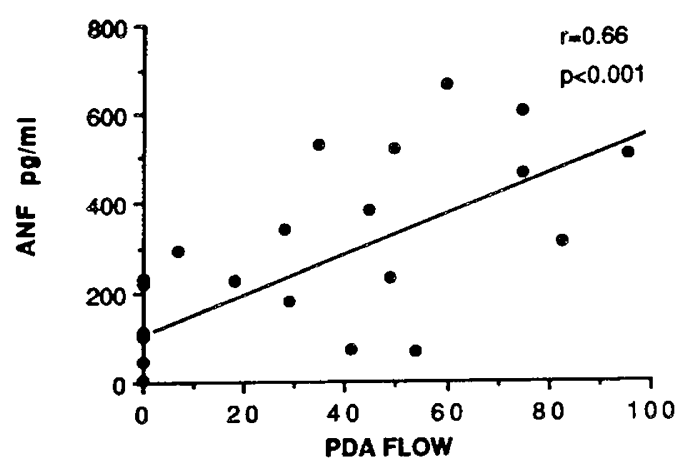

Fig. 4. Correlation of plasma ANF concentration and ductal flow. The ductal flow is expressed as percent turbulent flow in the main pulmonary artery.

decrease in flow stimulus in left atrium, ANF concentration falls immediately, as shown after operative closure of the duct (17). In the children in this series, ANF may have been secreted by both atria. This would explain why the correlation with a flow variable (turbulent area) was better than with left atrial stretching (LA/Ao ratio).

In preterm infants with RDS, the ductus frequently remains patent during the first few days of life $(18,19)$. The cardiorespiratory status in these neonates with RDS changes rapidly. In addition to anatomical size and degree of contraction, ductal flow is dependent on factors such as acidosis, hypoxia, and respirator settings. The amount of flow between the ductus and aorta is dependent on the pressure gradient between the pulmonary artery and the aorta. Cardiac output also varies. Plasma ANF level is probably influenced by many of these changes.

Infusion of ANF in healthy adults initiates natriuresis, diuresis, and vasodilatation at plasma concentrations over $100 \mathrm{pg} / \mathrm{mL}$ (10), but even smaller elevations may influence on natriuresis and blood pressure (20). ANF concentrations in our patients were considerably higher, suggesting that the factor may play a role in determining the extracellular fluid volume and blood pressure. Moreover, ANF has interactions with other hormones, for example in congestive heart failure high levels of ANF and vasoactive hormones such as renin and norepinephrine are found (21). Increased endothelial cell permeability due to ANF (4) may have an adverse effect on RDS. High plasma ANF measurements in these infants probably reflect their labile hemodynamic status and severe disease, but presently ANF measurements are not useful in clinical decision making.

\section{REFERENCES}

1. Sato F, Kamoi K, Wakiya Y, Ozawa T, Arai O, Ishibashi M, Yamaji T 1986 Relationship between atrial natriuretic peptide levels and atrial pressure in man. J Clin Endocrinol Metab 63:823-827

2. Weil J, Bidlingmaier C, Dohlemann U, Kuhnle $T$, Strom T, Lang RE 1986 Comparison of plasma atrial natriuretic peptide levels in healthy children from birth to adolescence and in children with cardiac diseases. Pediatr Res 20:1328-1331

3. Kikuchi K, Shiomi M, Horie K, Ohie T, Nakao K, Imura H, Mikawa H 1988 Plasma atrial natriuretic polypeptide concentration in healthy children from birth to adolescence. Acta Paediatr Scand 77:380-384

4. Atlas SA 1986 Atrial natriuretic factor: renal and systemic effects. Hosp Pract 21:67-77

5. Anderson JV, Bloom SR 1986 Atrial natriuretic peptide: what is the excitement all about? J Endocrinol 110:7-17

6. Shaffer SG, Geer PG, Goetz KL 1986 Elevated atrial natriuretic factor in neonates with respiratory distress syndrome. J Pediatr 109:1028-1033

7. Kojima T, Hirata Y, Fukuda Y, Iwase S, Kobayashi Y 1987 Plasma atrial natriuretic peptide and spontaneous diuresis in sick neonates. Arch Dis Child 62:667-670

8. Pesonen E, Simpson I, Breuer J, Reichman RT, Swenson R, Elias W 1988 Quantitation of experimental ductus arteriosus shunt flow by color flow mapping. J Amer Coll Cardiol 11:241A

9. Gilbert R, Keighley JF 1974 The arterial/alveolar oxygen tension ratio: an index of gas exchange applicable to varying oxygen concentrations. Am Rev Respir Dis 109:142-145

10. Tikkanen I, Fyhrquist F, Metsärinne K, Leidenius R 1985 Plasma atrial natriuretic peptide in cardiac disease and during infusions of healthy volunteers. Lancet 2:66-69

11. Meijboom EJ, Valdes-Cruz LM, Horowitz BS, Sahn DJ, Larson DF, Young KA, Lima CO, Goldberg SJ, Allen HD 1983 A two-dimensional Doppler echocardiographic method for calculation of pulmonary and systemic blood flow in a canine model with a variable-sized left-to-right extracardiac shunt. Circulation 68:437-445

12. Hiraishi S, Horiguchi Y, Misawa H, Oguchi K, Kadoi N, Fujino N, Yashiro K 1987 Noninvasive Doppler echocardiographic evaluation of shunt flow dynamics of the ductus arteriosus. Circulation 75:1146-1153

13. Swenson RE, Valdez-Cruz LM, Sahn DJ, Sherman FS, Chung KJ, Scagnelli S Hagen-Ansert S 1986. Realtime Doppler color flow mapping for detection of patent ductus arteriosus. J Am Coll Cardiol 8:1105-1112

14. Daniels O, Hopman JCW, Stoelinga CBA, Busch HJ, Peer PGM 1986 Doppler flow characteristics in the main pulmonary artery and LA/Ao ratio before and after ductal closure in healthy newborns. Pediatr Cardiol 3:99-104

15. Silverman NH, Lewis AB, Heymann MA, Rudolph AM 1974 Echocardiographic assesment of ductus arteriosus shunt in premature infants. Circulation $50: 821-825$

16. Pesonen E, Sherman F, Breuer J, Simpson I, Elias W, Sahn DJ, Andersson S, Tikkanen I, Fyhrquist F, Reichman R 1989 Experimental ductus arteriosus: the relationship of atrial pressure, dilatation and flow in ANF secretion. Life Sci 45:553-558

17. Andersson S, Tikkanen I, Pesonen E, Meretoja O, Hynynen M, Fyhrquist F 1987 Atrial natriuretic peptide in patent ductus arteriosus. Pediatr Res 21:396-398

18. Daniels O, Hopman JCW, Stoelinga CBA, Busch HJ, Peer PGM 1981 A combined Doppler echocardiographic investigation in premature infants with and without respiratory distress syndrome. In: Rijsterperg J (ed) Echocardiography. Nijhoff Publishers, The Hague pp 409-415

19. Merritt AT, Harris JP, Roghmann K, Wood B, Campanella V, Alexson C, Manning J, Shapiro DL 1981 Early closure of the patent ductus arteriosus in very low-birth-weight infants: a controlled trial. J Pediatr 99:281-286

20. Espiner EA, Richards AM 1989 Atrial natriuretic peptide. An important factor in sodium and blood pressure regulation. Lancet 1:707-710

21. Gottlieb S, Kukin ML, Ahern D, Packer M 1989 Prognostic importance of atrial natriuretic peptide in patients with chronic heart failure. J Am Coll Cardiol 13:1534-1539 